\title{
PERATAAN LABA DAN VARIABEL-VARIABEL YANG MEMPENGARUHINYA \\ (STUDI EMPIRIS PERUSAHAAN MANUFAKTUR YANG TERDAFTAR DI BEJ)
}

\author{
Purweni Widhianningrum \\ Pendidikan Akuntansi IKIP PGRI Madiun \\ weni.widhi@gmail.com
}

\begin{abstract}
This study aimed to determine the effect of managerial ownership, institutional ownership, debt financing, ownership dispersion, profitability, and firm size simultaneously and partially on income smoothing.This study uses manufacturing companies listed on the Jakarta Stock Exchange as an object of research. Based on purposive sampling method there are 147 companies that found the above criteria. Data analysis method used is multiple regression analysis. The results of this study showed that ownership dispersion and size of company that has a significant effect partially on income smoothing. The larger company and expanding company's ownership structure has greater freedom to report better earnings.
\end{abstract}

Key words: income smoothing, managerial ownership, institutional ownership, debt financing, ownership dispersion, profitability, and firm size.

\begin{abstract}
ABSTRAK
Penelitian ini bertujuan untuk mengetahui pengaruh signifikan dari variabel-variabel kepemilikan manjerial, kepemilikan institusi, debt financing, penyebaran kepemilikan, profitabilitas, dan ukuran perusahaan secara simultan dan parsial terhadap perataan laba. Penelitian ini menggunakan perusahaan manufaktur yang terdaftar di Bursa Efek Jakarta sebagai objek penelitian. Berdasarkan metode purposive sampling terdapat 147 perusahaan yang memenuhi kriteria. Metode analisis data yang digunakan adalah analisis regresi berganda. Hasil penelitian ini menunjukkan bahwa hanya variabel penyebaran kepemilikan dan ukuran perusahaan yang memiliki pengaruh signifikan secara parsial terhadap perataan laba. Hal ini dikarenakan semakin besar perusahaan dan semakin luas struktur kepemilikan maka perusahaan mempunyai kebebasan yang lebih besar untuk melaporkan laba yang lebih baik.
\end{abstract}

Kata kunci: perataan laba kepemilikan manjerial, kepemilikan institusi, debt financing, penyebaran kepemilikan, profitabilitas, dan ukuran perusahaan.

\section{PENDAHULUAN}

Laba merupakan komponen laporan keuangan perusahaan yang bertujuan untuk menilai kinerja manajemen, membantu mengestimasi kemampuan laba yang representastif dalam jangka panjang, meramalkan laba, menaksir risiko dalam berinvestasi. Hal ini disadari oleh manajemen perusahaan, sehingga manajemen cenderung melakuakan disfunctional behavior (perilaku tidak semestinya) yaitu dengan melakukan perataan laba untuk mengatasi berbagai konflik yang timbul antara 
manajemen dengan berbagai pihak yang berkepentingan dengan perusahaan (Sugiarto, 2003:350).

Disfungtional behaviour tersebut dipengaruhi oleh adanya asimetri informasi (information asymetry) dalam konsep teori keagenan. Asimetri informasi terjadi ketika manajer memiliki informasi internal perusahaan relatif lebih banyak dan mengetahui informasi tersebut relatif lebih cepat dibandingkan dengan pihak eksternal. Dalam kondisi tersebut, manajer dapat menggunakan informasi yang diketahuinya untuk memanipulasi laporan keuangan sebagai usaha untuk memaksimalkan kemakmurannya (Salno dan Baridwan, 2000). Perataan laba adalah cara yang digunakan manajemen untuk mengurangi fluktuasi laba yang dilaporkan agar sesuai dengan target yang diinginkan baik melalui metode akuntansi atau transaksi (Koch, 1981 dalam Irawati dan Maya, 2007).

Pembahasan konsep perataan laba ini tak lepas dari teori keagenan. Jensen dan Meckling (1976:5) mendefinisikan hubungan keagenan sebagai sebuah kontrak dimana satu atau lebih pemberi kerja (principal) menyewa orang lain (agent) untuk melakukan beberapa jasa untuk kepentingan principal dengan mendelegasikan beberapa wewenang untuk membuat keputusan kepada agent. Sebagai agent, manajer secara moral bertanggung jawab untuk mengoptimalkan keuntungan para pemilik (principal), namun disisi yang lain manajer juga mempunyai kepentingan memaksimumkan kesejahteraan mereka. Sehingga ada kemungkinan besar agent tidak selalu bertindak demi kepentingan terbaik principal.

Praktik perataan laba keuangan merupakan salah satu topik penelitian yang banyak diminati, hal ini terlihat dengan banyaknya penelitaan baik dalam dan luar negeri untuk membuktikan adanya praktik perusahaan di perusahaan dan faktor-faktor yang mempengaruhinya. Hasil studi empiris Carlson dan Bathala (1997), Budhijono (2006), Prabayanti dan Yasa (2009), dan Silviana (2010) menunjukkan bahwa variabel ukuran perusahaan dan profitabilitas mempengaruhi praktik perataan laba. Sedangkan hasil studi empiris Jin dan Machfoedz (1998) membuktikan bahwa leverage operasi berpengaruh terhadap perataan laba.

Berdasarkan latar belakang yang telah dijelaskan di atas, maka masalah dalam penelitian ini dapat dikemukakan sebagai berikut: (1) Apakah variabel-variabel kepemilikan manjerial, kepemilikan institusi, debt financing, penyebaran kepemilikan, profitabilitas, dan ukuran perusahaan berpengaruh signifikan secara simultan terhadap perataan laba?; (2) Apakah variabel-variabel kepemilikan manjerial, kepemilikan institusi, debt financing, penyebaran kepemilikan, profitabilitas, dan ukuran perusahaan berpengaruh signifikan secara parsial terhadap perataan laba?

\section{TELAAH LITERATUR}

Carlson dan Bathala (1997) dalam studi empirisnya yang berjudul "Ownership differences and firms' income smoothing behavior", bertujuan untuk menegtahui faktorfaktor insider ownership, institutional ownership, debt financing, ownership dispersion, incentive mechanisms, firm profitability, dan firm size yang mempengaruhi perataan laba pada perusahaan yang berbeda. Metode analisis yang digunakan adalah regresi logistik. Hasil penelitian menunjukkan bahwa insider ownership, institutional ownership, debt financing, ownership dispersion, incentive mechanisms, firm profitability, dan firm size berpengaruh terhadap perataan laba.

Jin dan Machfoedz (1998) dalam studi empirisnya yang berjudul " Faktor-faktor yang mempengaruhi praktik perataan laba pada perusahaan laba yang terdaftar di Bursa Efek Jakarta", bertujuan untuk mengetahui pengaruh dari faktor-faktor ukuran 
perusahaan, profitabilitas, sektor industri dan leverage operasi perusahaan terhadap perataan laba. Metode analisis yang digunakan adalah regresi logistik. Hasil penelitian ini menunjukkan bahwa leverage operasi merupakan faktor pendorong terjadinya praktik perataan laba.

Juniarti dan Corolina (2002) dalam studi empirisnya yang berjudul " Analisa faktor-faktor yang berpengaruh terhadap perataan laba (Income Smoothing) pada perusahaan-perusahaan Go Public", bertujuan untuk mengetahui pengaruh besaran perusahaan, profitabilitas, sektor industri perusahaan terhadap terjadinya perataan laba. Penelitian ini menggunakan meode analisis multivariat dengan regresi logistik binomial. Hasil penelitian ini menunjukkan bahwa besaran perusahaan, profitabilitas, sektor industri perusahaan tidak mempunyai pengaruh terhadap perataan laba. Hal ini dikarenakan rentang waktu penelitian tidak diperhitungkan sehingga rentang waktu penelitian tidak dimungkinkan akan berdampak pada tidak signifikannya hasil penelitian.

Budhijono (2006) dalam studi empirisnya yang berjudul "Evaluasi Perataan Laba Pada Industri Manufaktur dan Lembaga Keuangan yang Terdaftar di BEJ", bertujuan untuk menguji factor-faktor yang mempengaruhi perataan laba pada perusahaan yang terdaftar di BEJ dengan menggunakan regresi logistik. Faktor-faktor yang diujikan adalah ukuran perusahaan, profitabilitas, sektor industry, operating leverage, dan winner/losser stock. Hasil regresi logistik menunjukkan bahwa ukuran perusahaan, profitabilitas dan winner/losser stock memiliki pengaruh terhadap praktik perataan laba.

Prabayanti dan Yasa (2009) dalam studi empirisnya yang berjudul "Perataan laba (Income Smoothing) dan Analisis Faktor-faktor yang mempengaruhinya" bertujuan untuk menguji pengaruh variabel ukuran perusahaan, profitabilitas, dan financial leverage terhadap praktik perataan laba. Selain itu, peneliti juga melibatkan mekanisme corporate governance yang diproksikan dengan kepemilikan saham institusional dan reputasi auditor eksternal untuk menguji pengaruhnya terhadap praktik perataan laba. Studi ini menggunakan regresi logistik karena variabel terikat yang digunakan dalam penelitian ini menggunakan variabel dummy. Hasil penelitian ini menunjukkan bahwa hanya variabel profitabilitas yang memiliki pengaruh terhadap praktik perataan laba.

Silviana (2010) dalam studi empirisnya yang berjudul " Analisis Perataan Laba (Income Smoothing): Faktor-faktor yang mempengaruhi perataan laba pada perusahaan manufaktur Sektor Industri Dasar dan Kimia yang terdaftar di Bursa Efek Indonesia (2005-2009)", bertujuan untuk mengetahui faktor-faktor ukuran perusahaan, Profitabilitas, Net Profit Margin, Financial Leverage, dan Debt to Equity Ratio yang berpengaruh terhadap perataan laba. Metode analisis yang digunakan adalah analisis regresi logistik, dengan jumlah populasi 56 perusahaan manufaktur sektor industri dasar dan kimia. Hasil penelitian menunjukkan bahwa hanya variabel ukuran perusahaan yang mempunyai pengaruh terhadap perataan laba.

Aji dan Mita (2010) dalam studi empirisnya yang berjudul "Pengaruh profitabilitas, risiko keuangan, nilai perusahaan, dan struktur kepemilikan terhadap praktek perataan laba: studi empiris perusahaan manufaktur yang terdaftar di BEI" bertujuan untuk menguji faktor-faktor profitabilitas, risiko keuangan, nilai perusahaan, dan struktur kepemilikan yang mempengaruhi praktek perataan laba yang dilakukan oleh manajemen. Metode analisis yang digunakan adalah analisis regresi berganda dengan menggunakan sampel perusahaan manufaktur yang terdaftar di BEI periode tahun 2002-2008. Hasil studi menunjukkan bahwa risiko keuangan dan nilai perusahaan berpengaruh terhadap praktek perataan laba. 


\section{HIPOTESIS}

Gambar kerangka pemikiran dibawah ini menjelaskan bahwa Perataan Laba perusahaan dipengaruhi oleh variabel Kepemilikan Manjerial, Kepemilikan Institusi, Debt financing, Penyebaran kepemilikan, Profitabilitas, dan Ukuran perusahaan.

Gambar 1

Model Kerangka Pemikiran

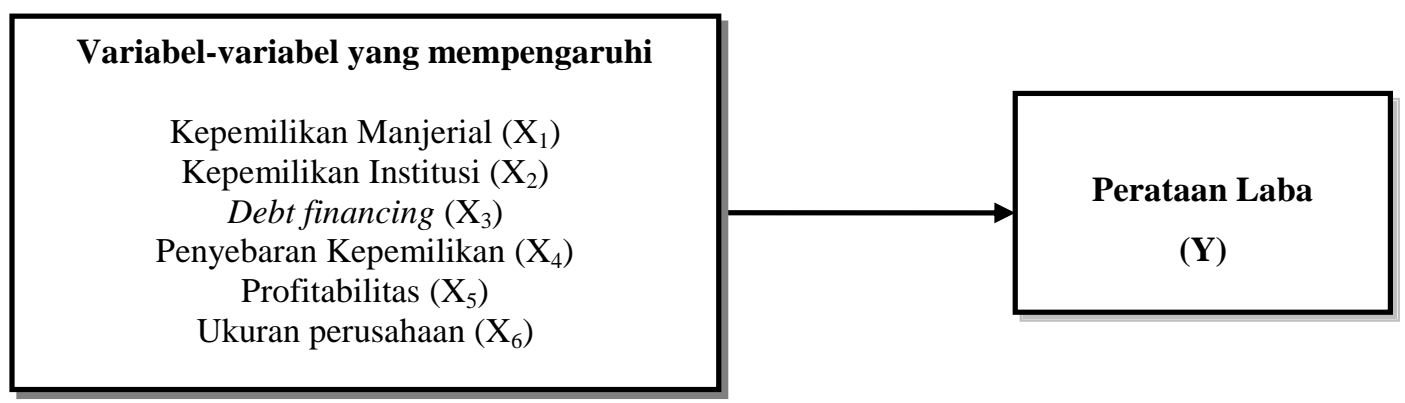

Berdasarkan kerangka pemikiran di atas, maka diajukan hipotesis penelitian sebagai berikut:

\section{Pengujian Hipotesis I}

Untuk menunjukkan pengaruh signifikan semua independen variabel yang dimasukkan dalam model terhadap dependent variabel secara simultan menggunakan likelihood ratio (LR) statistic.

$\mathrm{H}_{\mathrm{a}}$ : Kepemilikan Manjerial $\left(\mathrm{X}_{1}\right)$, Kepemilikan Institusi $\left(\mathrm{X}_{2}\right)$, Debt financing $\left(\mathrm{X}_{3}\right)$, Penyebaran Kepemilikan $\left(\mathrm{X}_{4}\right)$, Profitabilitas $\left(\mathrm{X}_{5}\right)$, dan Ukuran perusahaan $\left(\mathrm{X}_{6}\right)$ berpengaruh signifikan secara simultan terhadap Perataan Laba (Li).

\section{Pengujian Hipotesis II}

Untuk menunjukan pengaruh independen variabel terhadap dependen variabel secara parsial menggunakan Uji Wald dengan tingkat signifikansi sebesar 0,05. Hipotesa statistiknya:

$\mathrm{Ha}_{1}$ : Kepemilikan Manajerial $\left(\mathrm{X}_{1}\right)$ berpengaruh signifikan secara parsial terhadap Perataan Laba (Li).

$\mathrm{Ha}_{2}$ : Kepemilikan Institusi $\left(\mathrm{X}_{2}\right)$ berpengaruh signifikan secara parsial terhadap Perataan Laba (Li).

$\mathrm{Ha}_{3}$ : Debt financing $\left(\mathrm{X}_{3}\right)$ berpengaruh signifikan secara parsial terhadap Perataan Laba (Li).

$\mathrm{Ha}_{4}$ : Penyebaran Kepemilikan $\left(\mathrm{X}_{4}\right)$ berpengaruh signifikan secara parsial terhadap Perataan Laba (Li).

$\mathrm{Ha}_{5}$ : Profitabilitas $\left(\mathrm{X}_{5}\right)$ berpengaruh signifikan secara parsial terhadap Perataan Laba (Li).

$\mathrm{Ha}_{6}$ : Ukuran Perusahaan $\left(\mathrm{X}_{6}\right)$ berpengaruh signifikan secara parsial terhadap Perataan Laba (Li).

\section{METODE PENELITIAN}

\section{Jenis dan Obyek Penelitian}

Jenis penelitian yang digunakan dalam penelitian ini adalah jenis penelitian assosiatif yaitu penelitian yang bertujuan untuk mengetahui hubungan antara dua variabel atau lebih (Sugiyono, 2001:11). 
Obyek penelitian yang digunakan adalah perusahaan yang terdaftar sebagai perusahaan manufaktur di Bursa Efek Indonesia selama lima tahun berturut-turut, yaitu periode 1999 sampai 2003. Alasan dipilihnya tahun tersebut sebagai obyek penelitian adalah kemungkinan perusahaan-perusahaan melakukan praktik perataan laba demi menarik minat investor untuk memulihkan kondisi ekonomi setelah krisis ekonomi tahun 1997 melanda kawasan Asia termasuk Indonesia .

\section{Populasi dan Pengambilan Sampel Penelitian}

Dalam penelitian ini populasi yang diteliti yaitu perusahaan-perusahaan yang terdaftar di Bursa Efek Indonesia. Pengambilan sample pada penelitian ini menggunakan metode purposive sampling, yaitu mengambil sample dari populasi berdasarkan suatu kriteria sebagai berikut:

1. Termasuk dalam perusahaan manufacturing.

2. Perusahaan menerbitkan laporan keuangan per 31 Desember untuk periode 19992003.

3. Data untuk semua variable penjelas tersedia

4. Laporan keuangan perusahaan tersedia di bursa selama periode 1999-2003.

Dari 153 populasi perusahaan manufaktur yang terdaftar di BEJ, tersaring 147 perusahaan yang dipilih sebagai sample akhir.

\section{Metode pengumpulan data}

Data yang digunakan dalam penelitian ini adalah melalui data sekunder. Data sekunder penelitian ini diperoleh dari Indonesian Capital Market Directory (ICMD) tahun 1999 dan 2004 di Pojok BEI Universitas Brawijaya yang menyajikan laporan keuangan masing-masing perusahaan selama lima tahun berturut-turut, yaitu mulai dari tahun 1999 sampai 2003.

Adapun data yang diperlukan adalah proporsi kepemilikan manajerial, proporsi kepemilikan institusi, proporsi kepemilikan saham biasa, total asset, Return On Assets (ROA), total hutang.

\section{Metode Analisis Data}

Metode yang dipakai adalah logit model, yaitu:

$$
\mathrm{Li}=\mathrm{Ln}\left(\frac{\mathrm{Pi}}{1-\mathrm{Pi}}\right)=\alpha+\beta_{1} \mathrm{X}_{1}+\beta_{2} \mathrm{X}_{2}+\beta_{3} \mathrm{X}_{3}+\beta_{4} \mathrm{X}_{4}+\beta_{5} \mathrm{X}_{5}+\beta_{6} \mathrm{X}_{6}+\mathrm{e}
$$

Keterangan:

$$
\begin{array}{ll}
\mathrm{Li} & =\mathrm{Y}=1 \text { income smoother } ; 0 \text { non income smoother } \\
\mathrm{X}_{1} & =\text { Kepemilikan Manjerial } \\
\mathrm{X}_{2} & =\text { Kepemilikan Institusi } \\
\mathrm{X}_{3} & =\text { Debt Financing } \\
\mathrm{X}_{4} & =\text { Penyebaran Kepemilikan } \\
\mathrm{X}_{5} & =\text { Profitabilitas } \\
\mathrm{X}_{6} & =\text { Ukuran Perusahaan } \\
\alpha & =\text { Konstanta regresi } \\
\beta & =\text { Koefisien regresi } \\
\mathrm{e} & =\text { Error term }
\end{array}
$$

Untuk menghitung logit model dengan individual data metode OLS atau weighted least square (WLS) tidak bisa dipergunakan. Sehingga metode maximum likelihood (ML) yang akan digunakan dalam perhitungan logit model di atas. 


\section{Variabel dan Pengukurannya}

- Perataan Laba (Li) sebagai variabel dependen. Peneliti membedakan perusahaan menjadi dua yaitu smoothers dan non smoothers. Kategori ini berdasarkan variabilitas pendapatan yang digunakan oleh Albrecht dab Richardson (1990) dan Carlson dan Bathala (1997). Pengukurannya:

$$
\begin{aligned}
\mathrm{CV}_{\mathrm{I}} & =\frac{\sigma \Delta \text { Income }}{\mu \Delta \text { Income }} \\
\mathrm{CV}_{\mathrm{S}} & =\frac{\sigma \Delta \text { Sales }}{\mu \Delta \text { Sales }} \\
\mathrm{CV}_{\mathrm{IS}} & =\frac{C V_{I}}{C V_{S}}
\end{aligned}
$$

Dimana :

$\Delta \mathrm{I}=$ Perubahan income (net income) dalam satu periode

$\Delta \mathrm{S}=$ Perubahan sales dalam satu periode

$\mathrm{CV}=$ Koefisien variasi dari variabel yaitu standar deviasi dibagi dengan expected return

Perusahaan digolongkan menjadi smoothers apabila: $\mathrm{CV}_{\mathrm{I}} \leq \mathrm{CV}_{\mathrm{S}}$

- Kepemilikan Manajerial $\left(\mathbf{X}_{\mathbf{1}}\right)$ sebagai variabel independen diukur dengan menggunakan proporsi kepemilikan saham dari para pemegang saham (direksi dan komisaris) yang berperan aktif dalam pengambilan keputusan (Carlson dan Bathala, 1997).

- Kepemilikan Institusi $\left(\mathbf{X}_{2}\right)$ sebagai variabel independen diukur dengan proporsi kepemilikan saham oleh pemilik institusi (bank, perusahaan asuransi, perusahaan investasi, dana pensiun, dan sebagainya), pengukuran ini mengacu pada penelitian Carlson dan Bathala (1997).

- Debt Financing $\left(\mathbf{X}_{3}\right)$ sebagai variabel independen diukur dengan rasio antara total hutang dibagi dengan total aset (Carlson dan Bathala, 1997). Debt Financing merupakan kemampuan perusahaan tersebut untuk melunasi utangnya dengan menggunakan aktiva yang dimiliki (Prabayanti dan Yasa, 2009).

- Penyebaran Kepemilikan $\left(\mathbf{X}_{4}\right)$ sebagai variabel independen diukur dari log natural jumlah pemegang saham biasa perusahaan. Penyebaran Kepemilikan Merupakan upaya untuk memperluas pasar saham perusahaan sehingga membawa pengaruh yang menguntungkan nilai saham perusahaan (Carlson dan Bathala, 1997).

- Profitabilitas $\left(\mathbf{X}_{5}\right)$ sebagai variabel independen diukur dengan Return On Asset, yaitu Laba bersih dibagi total asset. Profitabilitas merupakan tingkat keuntungan bersih yang mampu diraih oleh perusahaan pada saat menjalankan operasinya (Jin dan Machfoedz, 1998:180).

- Ukuran Perusahaan $\left(\mathbf{X}_{\mathbf{6}}\right)$ sebagai variabel independen diukur dengan menggunakan log natural (Ln) dari total asset. Ukuran perusahaan digunakan untuk mencerminkan besar kecilnya aset yang dimiliki perusahaan (Carlson dan Bathala, 1997).

\section{HASIL PENELITIAN DAN PEMBAHASAN \\ Pengujian Hipotesis Satu}

Pengujian hipotesis satu digunakan untuk menunjukkan apakah semua variabel yang dimasukkan dalam model mempunyai pengaruh signifikan secara simultan terhadap 
dependen variabel, maka digunakan likelihood ratio statistik dengan tingkat signifikansi 0,05 . Hasil pengujian disajikan pada tabel 1 berikut ini.

\section{Tabel 1}

Pengujian Secara Simultan

\begin{tabular}{lccc}
\hline \multicolumn{1}{c}{ Variabel } & $\begin{array}{c}\mathbf{- 2} \text { Log } \\
\text { Likelihood }\end{array}$ & $\begin{array}{c}\text { Cox \& Snell } \\
\text { R Square }\end{array}$ & $\begin{array}{c}\text { Negelkerke } \\
\text { R Square }\end{array}$ \\
\hline $\begin{array}{l}\text { Kepemilikan Manjerial, Kepemilikan } \\
\text { Institusi, Debt financing, Penyebaran }\end{array}$ & 528,055 & 0,023 & 0,032 \\
kepemilikan, Profitabilitas, dan Ukuran \\
perusahaan
\end{tabular}

Berdasarkan pada tabel di atas, nilai -2 Log Likelihood sebesar 528,055. Dengan angka sedemikian besar, maka dapat disimpulkan bahwa model yang terdiri dari seluruh variabel signifikan secara statistik pada $\alpha=5 \%$.

Nilai Cox and Snell R Square sebesar 0,023 menunjukkan bahwa variasi nilai Li yang dapat dijelaskan oleh persamaan regresi yang diperoleh sebesar 2,3\% sedangkan sisanya yaitu 97,7\% dijelaskan oleh variabel lain di luar persamaan model. Negelkerke $\mathrm{R}$ Square sebesar 0,032 artinya pengaruh antara variabel Kepemilikan Manjerial, Kepemilikan Institusi, Debt financing, Penyebaran kepemilikan, Profitabilitas, dan Ukuran perusahaan adalah lemah.

\section{Pengujian Hipotesis Dua}

Pengujian hipotesis dua digunakan untuk melihat pengaruh signifikan variabel independen secara parsial terhadap variabel dependen, maka digunakan uji Wald dengan tingkat signifikansi sebesar 0,05. Uji Wald dilakukan dengan mensortir nilainilai data dari yang terkecil ke yang besar dan selanjutnya run test dalam jumlah atau urutan group.

\section{Tabel 2}

\section{Pengujian Secara Parsial}

\begin{tabular}{lccc}
\hline \multicolumn{1}{c}{ Variabel } & $\begin{array}{c}\text { Unstandardized } \\
\text { Coefficient }(\boldsymbol{\beta})\end{array}$ & Uji Wald & Sig \\
\hline Kepemilikan Manajerial $\left(\mathrm{X}_{1}\right)$ & 0,0006 & 0,003 & 0,957 \\
Kepemilikan Institusi $\left(\mathrm{X}_{2}\right)$ & $-0,0026$ & 0,196 & 0,658 \\
Debt Financing $\left(\mathrm{X}_{3}\right)$ & 0,0007 & 0,245 & 0,621 \\
Penyebaran kepemilikan $\left(\mathrm{X}_{4}\right)$ & 0,3275 & 5,832 & $0,016^{*}$ \\
Profitabilitas $\left(\mathrm{X}_{5}\right)$ & $-0,0004$ & 0,015 & 0,903 \\
Ukuran perusahaan $\left(\mathrm{X}_{6}\right)$ & $-0,3719$ & 7,901 & $0,005^{*}$ \\
(Constant) & 0,9230 & 0,168 & 0,682 \\
\hline
\end{tabular}

Keterangan: * Signifikan pada level 0,05

Sumber: data diolah

Berdasarkan pada tabel di atas, maka persamaan model logistik yang didapat adalah sebagai berikut:

$$
\text { Ln } \frac{P}{1-P}=0,9230+0,0006 \mathrm{X}_{1}-0,0026 \mathrm{X}_{2}+0,0007 \mathrm{X}_{3}+0,3275 \mathrm{X}_{4}-0,0004 \mathrm{X}_{5}-0,3719 \mathrm{X}_{6}+\mathrm{e}
$$

Nilai konstan sebesar 0,9230 menunjukkan bahwa apabila tidak ada Kepemilikan Manjerial, Kepemilikan Institusi, Debt financing, Penyebaran 
kepemilikan, Profitabilitas, dan Ukuran perusahaan $\left(\mathrm{X}_{1}, \mathrm{X}_{2}, \mathrm{X}_{3}, \mathrm{X}_{4}, \mathrm{X}_{5}\right.$, dan $\left.\mathrm{X}_{6}=0\right)$ maka income smoother sebesar -0,09230.

\section{Pengaruh Kepemilikan Manajerial Terhadap Perataan Laba}

Hasil penelitian ini menunjukkan bahwa Variabel Kepemilikan Manjerial $\left(\mathrm{X}_{1}\right)$ mempunyai nilai signifikan sebesar 0,957. Nilai ini lebih besar dari 0,05 $(0,957>0,05)$. Sehingga dapat dijelaskan bahwa variabel Kepemilikan Manjerial $\left(\mathrm{X}_{1}\right)$ secara parsial tidak mempunyai pengaruh signifikan terhadap perataan laba (Li).

Hasil penelitian ini mendukung penelitian yang dilakukan oleh Aji dan Mita (2010) yang tidak berhasil membuktikan bahwa kepemilikan manajerial merupakan faktor pendorong terjadinya praktik perataan laba. Hal ini menandakan bahwa dengan adanya kepemilikan manajerial tidak serta merta menunjukkan insentif manajemen untuk melakukan praktek perataan laba karena hal tersebut mungkin dapat membahayakan perusahaan dalam jangka panjang.

\section{Pengaruh Kepemilikan Institusi Terhadap Perataan Laba}

Hasil penelitian ini menunjukkan bahwa variabel kepemilikan institusi $\left(\mathrm{X}_{2}\right)$ mempunyai nilai signifikan sebesar 0,658. Nilai ini lebih besar dari 0,05 $(0,658>0,05)$. Sehingga dapat dijelaskan bahwa variabel kepemilikan institusi $\left(\mathrm{X}_{2}\right)$ secara parsial tidak mempunyai pengaruh signifikan terhadap perataan laba (Li).

Tidak berpengaruhnya variabel kepemilikan institusi dikarenakan kurangnya mekanisme monitoring yang efektif oleh pihak institutional atas kontrol perusahaan. Menurut Cai et al. (2001) dalam Faisal (2005:179) yang menyatakan bahwa perusahaan dengan kepemilikan institutional yang besar (lebih dari 5\%) mengindikasikan kemampuan untuk memonitor manajemen. Semakin besar kepemilikan institutional maka semakin efisien pemanfaatan aktiva perusahaan. Dengan demikian proporsi kepemilikan institutional sebagai pencegahan terhadap pemborosan yang dilakukan manajemen.

\section{Pengaruh Debt Financing Terhadap Perataan Laba}

Hasil penelitian ini menunjukkan bahwa variabel Debt Financing $\left(\mathrm{X}_{3}\right)$ mempunyai nilai signifikan sebesar 0,621. Nilai ini lebih besar dari 0,05 $(0,621>0,05)$. Sehingga dapat dijelaskan bahwa variabel Debt Financing $\left(\mathrm{X}_{3}\right)$ secara parsial tidak mempunyai pengaruh signifikan terhadap perataan laba (Li).

Hal ini dikarenakan ketika proporsi hutang lebih kecil, perjanjian hutang mungkin tidak terlalu keras, dan mungkin perusahaan tidak menggunakan perataan laba sebagai metode untuk memenuhi perjanjian hutangnya (Calrson dan Chenchuramaiah, 1997:191).

\section{Pengaruh Penyebaran kepemilikan Terhadap Perataan Laba}

Hasil penelitian ini menunjukkan bahwa variabel penyebaran kepemilikan $\left(\mathrm{X}_{4}\right)$ mempunyai nilai signifikan sebesar 0,016. Nilai ini kurang dari $0,05(0,016<0,05)$. Sehingga dapat dijelaskan bahwa variabel penyebaran kepemilikan $\left(\mathrm{X}_{4}\right)$ secara parsial mempunyai pengaruh signifikan terhadap perataan laba (Li).

Hasil penelitian ini konsisten dengan Carlson dan Chenchuramaiah (1997) yang menyimpulkan bahwa struktur kepemilikan yang luas mempunyai kebebasan yang lebih besar untuk melaporkan laba yang lebih baik. Pola laba periode yang stabil dapat mendukung tingkat dividen yang lebih tinggi dibanding pola laba periode yang berfluktuasi dan diharapkan perataan laba memberi pengaruh yang menguntungkan nilai saham perusahaan karena risiko perusahaan dapat dikurangi.

\section{Pengaruh Profitabilitas (Return On Asset) Terhadap Perataan Laba}

Hasil penelitian ini menunjukkan bahwa variabel profitabilitas $\left(\mathrm{X}_{5}\right)$ mempunyai nilai signifikan sebesar 0,903. Nilai ini lebih besar dari 0,05 $(0,903>0,05)$. Sehingga 
dapat dijelaskan bahwa variabel Firm profitabilitas $\left(\mathrm{X}_{5}\right)$ secara parsial tidak mempunyai pengaruh signifikan terhadap perataan laba (Li).

Hasil penelitian ini sejalan dengan temuan Jin dan Machfoedz (1998) yang tidak berhasil membuktikan adanya pengaruh variabel profitabilitas terhadap perataan laba. Hal ini menunjukkan adanya kemungkinan investor tidak hanya mempertimbangkan profitabilitas perusahaan dalam pengambilan keputusan investasi, namun juga berdasarkan faktor lain seperti likuiditas perusahaan dan tingkat hutang perusahaan.

\section{Pengaruh Ukuran Perusahaan Terhadap Perataan Laba}

Hasil penelitian ini menunjukkan bahwa variabel ukuran perusahaan $\left(\mathrm{X}_{6}\right)$ mempunyai nilai signifikan sebesar 0,005 . Nilai ini lebih kecil dari $0,05(0,005<0,05)$. Sehingga dapat dijelaskan bahwa variabel ukuran perusahaan $\left(\mathrm{X}_{6}\right)$ secara parsial mempunyai pengaruh signifikan terhadap perataan laba (Li).

Hasil penelitian ini sejalan dengan hasil penelitian Carlson dan Bathala (1997), Budhijono (2006), dan Silviana (2010). Menurut Watts dan Zimmerman (1986) yang menyatakan bahwa perusahaan besar menghadapi bahaya politis yang lebih besar karena merupakan entitas yang banyak disorot oleh publik secara umum. Para karyawan berkepentingan melihat kenaikan laba sebagai acuan untuk meningkatkan kesejahteraannya melalui kenaikan gaji. Pemerintah melihat kenaikan laba perusahaan sebagai obyek pajak yang akan ditagihkan sehingga pilihan yang dialami oleh organisasi adalah dengan cara bagaimana lewat proses akuntansi agar laba dapat ditampilkan lebih rendah. Alasan lain yang dapat diberikan adalah perusahaan yang lebih besar lebih mungkin untuk matang dan mempunyai pendapatan dan laba yang tersinkronisasi (Carlson dan Chenchuramaiah, 1997:184)

\section{KESIMPULAN}

Berdasarkan tujuan penelitian dan pembahasan yang dijelaskan di atas, maka dapat diambil suatu kesimpulan bahwa dalam penelitian ini hanya variabel penyebaran kepemilikan dan ukuran perusahaan yang memiliki pengaruh signifikan secara parsial terhadap perataan laba. Hal ini dikarenakan semakin besar perusahaan dan semakin luas struktur kepemilikan maka perusahaan mempunyai kebebasan yang lebih besar untuk melaporkan laba yang lebih baik. Sedangkan variabel-variabel lainnya seperti: kepemilikan manajerial, kepemilikan institusi, debt financing dan profitabilitas tidak mempengaruhi praktik perataan laba. Berdasarkan pada hasil penelitian yang telah dibahas pada bab sebelumnya, maka saran untuk perbaikan pada penelitian berikutnya sebagai berikut: (1) Penelitian selanjutnya diharapkan dapat menambah jumlah sampel yang digunakan dengan memperluas cakupan perusahaan dan memperpanjang periode waktu yang digunakan. (2) Penelitian selanjutnya diharapkan dapat memperluas objek penelitian pada seluruh perusahaan yang terdaftar di Bursa Efek Indonesia.

\section{DAFTAR PUSTAKA}

Albrecht, W.D and F.M. Richardson. 1990. Income Smoothing by Economic Sector. Journal of Business Finance and Accounting, Vol. 17, No. 5, p.717-729.

Aji, Dhamar Yudho dan Aria Farah Mita. 2010. Pengaruh profitabilitas, risiko keuangan, nilai perusahaan, dan struktur kepemilikan terhadap praktek perataan laba: studi empiris perusahaan manufaktur yang terdaftar di BEI. Simposium Nasional Akuntansi, XIII, Purwokerto. 
Belkaoui, Ahmed Riahi. 1992. Accounting Theory. Third Edition, London: Academic Press Limited.

Budhijono, Fongnawati. September 2006. Evaluasi Perataan Laba Pada Industri Manufaktur dan Lembaga Keuangan yang Terdaftar di BEJ. ISSN 1412 - 0240, Vol 6, No. 1.

Calson, Steven J and Chenchuramaiah T Bathala. 1995. Ownership Differences and Firms' Income Smoothing Behavior. Journal of Business Finance and Accounting, 24(2), p. 179-195.

Faisal. 2005. Analisis Agency Costs, Struktur Kepemilikan dan Mekanisme Corporate Governance. Jurnal Riset Akuntansi Indonesia, Vol. 8, No. 2, p.175-190.

Irawati, Zulfa dan Anugerah Maya A. Juni 2007. Analisis Perataan Laba (Income Smoothing): Faktor yang Mempengaruhinya dan Pengaruhnya Terhadap Return dan Risiko Saham Perusahaan Go Publik di Bursa Efek Jakarta. BENEFIT. Vol 11, No. 1.

Jensen, Michael C. Mei 1986. Agency Cost of Free Cash Flow, Corporate Finance, and Takeovers. American economic Review. Vol. 76, No. 2, p.323-329.

Jin, Liauw She dan Mas'ud Machfoedz. 1998. Faktor-faktor Yang Mempengaruhi Praktik Perataan Laba Pada Perusahaan Yang Terdaftar di Bursa Efek Jakarta. Jurnal Riset Akuntansi Indonesia, Vol. 1, No. 2, p.174-191.

Juniarti dan Corolina. 2002. Analisa Faktor-Faktor yang Berpengaruh Terhadap Perataan Laba (Income Smooting) pada Perusahaan Go Public. Jurnal Ekonomi Universitas Kristen Petra Surabaya.

Prabayanti, Ni Luh Putu Arik dan Gerianta Wirawan Yasa. 2009. Perataan Laba (Income Smoothing) dan Analisis Faktor-faktor yang Mempengaruhinya. ISSN.

Salno, Hanna Meilani dan Zaki Baridwan. 2000. Analisis Perataan Penghasilan (Income Smoothing): Faktor-faktor yang Mempengaruhi dan Kaitannya dengan Kinerja Saham Perusahaan Publik Indonesia. Jurnal Riset Akuntansi Indonesia, Vol.3, No.1, p.17-34.

Silviana. 2010. Analisis Perataan Laba (Income Smoothing): Faktor-faktor yang mempengaruhi perataan laba pada perusahaan manufaktur Sektor Industri Dasar dan Kimia yang terdaftar di Bursa Efek Indonesia (2005-2009). Diunduh pada tanggal 16 februari 2011 , http://www.gunadarma.ac.id

Sugiarto, Sopa. Oktober 2003. Perataan Laba dalam Mengantisipasi Laba Masa Depan Perusahaan Manufaktur yang Terdaftar di Bursa Efek Jakarta. Simposium Nasional Akuntansi VI Surabaya, p.350-358.

Sugiyono. 2001. Metode Penelitian Bisnis. CV Alphabeta, Bandung. 